\title{
Behavior resulting from fire in plasterboard with plastic cable waste aggregates
}

\author{
Alejandra Vidales-Barriguete ${ }^{\text {a, *, }}$ Carolina Piña-Ramírez ${ }^{\mathrm{b}}$, Rubén Serrano-Somolinos ${ }^{\mathrm{a}}$, \\ Mercedes del Río-Merino ${ }^{\mathrm{b}}$, Evangelina Atanes-Sánchez ${ }^{\mathrm{c}}$ \\ ${ }^{a}$ Universidad Politécnica de Madrid, Escuela Técnica Superior de Edificación, Departamento de Tecnología de la Edificación, Spain \\ ${ }^{\mathrm{b}}$ Universidad Politécnica de Madrid, Escuela Técnica Superior de Edificación, Departamento de Construcciones Arquitectónicas y su Control, Spain \\ ${ }^{\mathrm{c}}$ Universidad Politécnica de Madrid, Escuela Técnica Superior de Ingeniería y Diseño Industrial, Departamento de Ingeniería Mecánica, Química y Diseño Industrial, \\ Spain
}

\section{A R T I C L E I N F O}

\section{Keywords:}

Fire behavior

Combustion gases

Plastic waste

Gypsum composites

Recycled plastic compounds

\begin{abstract}
A B S T R A C T
This article analyzes the effect of fire on plasterboards with aggregates of plastic cable waste, considering the plaster coating as a strategy to reduce the flammability of the added polymers. A real test was performed, using a direct fire set in a Madrid fire station, and a theoretical estimate of the composition of the gas emissions, focused in $\mathrm{CO}_{2}$ and $\mathrm{CO}$, during a fire in a type room is presented. The results reflect that there is no clear trend between the evolution of temperatures over time and the amount of plastic waste added to the plaster matrix in the different specimens, but a different behavior is obtained depending on the surroundings where they are located. Temperatures of $600{ }^{\circ} \mathrm{C}$ are reached between 5 and $10 \mathrm{~min}$ after the start of the fire if they are located in a place with heat containment, and they do not reach $400^{\circ} \mathrm{C}$ in the same period of time in a place with less heat containment. It was also observed that gypsum can be considered a passive protection of polymers, as it retards the effect of the flame on them. Concerning the gases released, the theoretical calculations, based on the elemental and thermogravimetric analysis of the plastic cable waste, reveal that the amount of carbon dioxide generated in a fire would not pose a risk to people's health whereas the values obtained for the carbon monoxide exceed the limited considered dangerous to health for a period greater than $15 \mathrm{~min}$. Using plastic cable waste as secondary raw material reduces the number of incinerations to be carried out in landfills with this type of waste, thereby decreasing the potential emission of contaminants into the atmosphere and contributing to the sustainability of our planet.
\end{abstract}

\section{Introduction}

In construction materials, an absolute requirement is knowledge of how these materials are affected by fire. This includes not only the danger of their being set on fire and the destruction of the construction element made up by the material but also the risk resulting from the production of combustion gases during the course of the same.

The development, evolution and consequences of a fire are complex phenomena that depend on the quantity and nature of the burning material as well as other factors. These other factors may also be decisive in the fire's development, and include building design, location, potential ignition sources, ventilation and environmental factors. In addition, the installation's design and form, as well as its protection and use, also play a major role in fire safety [1]. Distinct materials participate in a fire, and plastics behave like other organic materials [2]. Specifically, manufacturers of plastics for use in construction tend to design their products in accordance with current European and national standards, developing products with improved and/or specific fire behavior characteristics [3-5]. Fire resistance testing of the construction materials, including the plastic materials, is based on a time-temperature curve that is defined in ISO standard 834 [6], which does not represent any type of natural fire. As mentioned above, a real fire depends on the characteristics of the location where it takes place, the type and quantity of fuel and the existing ventilation conditions. Therefore, the analysis of the effects resulting in a material that has been affected by a real fire is essential. A real fire occurs in the following phases: ignition, latent fire, heating and cooling [7].

On the other hand, in addition to the risk from the excessive

\footnotetext{
* Corresponding author. Universidad Politécnica de Madrid, Avda. Juan de Herrera, 6, 28040, Madrid, Spain.

E-mail address: alejandra.vidales@upm.es (A. Vidales-Barriguete).
} 
temperatures that may arise during a fire, smoke also represents a major threat to individuals, and therefore, it is important to examine the gases produced in a combustion. Of all of the contaminants generated in the polymer combustion process, the following are of special note [8]: carbon monoxide (CO) [1,9], carbon dioxide $\left(\mathrm{CO}_{2}\right)$ [1,10], volatile heavy metals [11], acid fumes [12], dioxins (PCDDs) and furans (PCDFs) [13]. It should be noted that gases produced in a combustion are the result of not only spontaneous fires, but also of plastic waste incineration facilities, where these products wind up, due to their heterogeneity and recycling difficulties. And it is here where the other mentioned substances, in addition to $\mathrm{CO}$ (fly ash, $\mathrm{HCl}, \mathrm{SO}_{2}, \mathrm{NOx}$, dioxins, furans, etc.), may be of special relevance [13]. In Spain, gaseous streams originating in these plants should be treated prior to their discharge to the environment, to comply with emissions thresholds established by Royal Decree 815/2013, of 18 October, approving the Regulation on industrial emissions and the development of Law 16/2002, of 1 July, on integrated contamination prevention and control [14].

When plastic burns, a thermo-oxidative reaction takes place which reduces the polymer's carbon chains to monomers, which are in turn reduced to $\mathrm{CO}_{2}$, water and other combustion products [15]. One of the strategies used to reduce the flammability of plastic materials and the effect of the same in a fire is the addition of flame retardants in their formulation. These increase the duration of the latent fire phase, permitting an increased exhaust time and a reduction in the risk of fire as well as the fire spread. However, another option is to establish phys$\mathrm{ical} / \mathrm{chemical}$ barriers between the polymer and the ignition source, such as reinforcement layers or plasterboard or mortar panels.

Some studies have examined the effects of fire on plastics [16-18], and more specifically, on the covering of plastic cables [19], in rubber construction elements in cement [20] and concrete [21] matrices, and even in plasterboard panels [22,23]. This study, unlike past works, considers the action of fire on plasterboard panels containing plastic waste aggregates, and whether or not the plaster may be considered a physical barrier between the polymer and the fire. In addition, with the manufacture of these panels, incinerations of this type of plastic wastes are reduced and, consequently, the potential release of contaminants in the atmosphere.

\section{Materials and methods}

\subsection{Materials}

For the creation of panels containing plastic waste aggregates from cables, the following materials were used:

- Fast-setting European A designation gypsum, in accordance with UNE EN 13279-1 [24] standard, manufactured by Placo.
- Water from Canal de Isabel II (Madrid), having the technical characteristics established in UNE EN 13279-2 standard [25].

- Plastic cable waste (PR), obtained from an unused cable recycling process. This waste, having a granulometric size of less than $3 \mathrm{~mm}$, consists of a heterogeneous mixture of thermostable polymers and thermoplastics (Fig. 1).

\subsection{Test sample preparation}

For the preparation of the test samples, indications from UNE EN 13279-2 standard were followed, as well as instructions from studies conducted by Serrano [26] and Piña [27]. Panels measuring $320 \pm 1.5 \mathrm{~mm} \times 150 \pm 1.5 \mathrm{~mm}$ with a thickness of $15 \mathrm{~mm}$ were prepared, having a water/plaster mass ratio of 0.8 . The quantity of the waste incorporated into the mixture was $50 \%-60 \%-70 \%$ (E0.8-50PR E0.8-60PR - E0.8-70PR) of the aggregate over the plaster mass (dosage in Table 1). In addition, a batch with no plastic waste was also created as a reference batch (E0.8).

During test sample preparation and in order to avoid the buoyancy of the waste, dry plaster and waste were mixed together for several seconds prior to adding the water and proceeding with mechanical mixing [28]. The samples were then stored in the laboratory for seven days (temperature of $23 \pm 2{ }^{\circ} \mathrm{C}$ and relative humidity of $35 \pm 5 \%$ ) as indicated in the UNE EN 13279-2 standard.

Finally, 12 panels were obtained, organized in 4 batches (Fig. 2); the first batch of 3 panels without waste (reference panels); the second batch of 3 panels with $50 \%$ waste; the third batch of 3 panels with $60 \%$ waste; and the fourth batch of 3 panels with $70 \%$ waste. All of these batches were subjected to direct fire testing, as used by the Fire Prevention and Extinction Department of the Autonomous Community of Madrid, in accordance with UNE EN 1363-1:2015 and UNE-EN 1363-2:2000 standards $[7,29,30]$.

Table 1

Composition of compounds.

\begin{tabular}{clllll}
\hline Panel & $\begin{array}{l}\text { Plaster } \\
(\%)\end{array}$ & $\begin{array}{l}\text { Water } \\
(\%)\end{array}$ & $\begin{array}{l}\text { Pellets } \\
(\%)\end{array}$ & $\begin{array}{l}\text { Bulk density } \\
\left(\mathrm{g} / \mathrm{cm}^{3}\right)\end{array}$ & $\begin{array}{l}\text { Weight at 7 } \\
\text { days }(\mathrm{g})\end{array}$ \\
\hline E0.8 & 100 & 80 & 0 & 1007.70 & 703.30 \\
$\begin{array}{c}\text { E0.8- } \\
\text { 50PR }\end{array}$ & 100 & 80 & 50 & 1016.40 & 778.20 \\
$\begin{array}{c}\text { E0.8- } \\
\text { 60PR }\end{array}$ & 100 & 80 & 60 & 1016.50 & 774.40 \\
$\begin{array}{c}\text { E0.8- } \\
\text { 70PR }\end{array}$ & 100 & 80 & 70 & 1015.10 & 796.60 \\
\hline
\end{tabular}

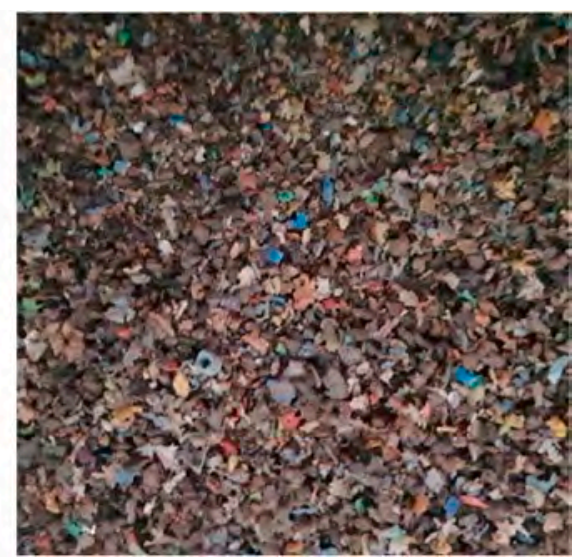

Fig. 1. (Left) cables in the recycling plant. (Right) plastic cable waste obtained after recycling. Source: Lyrsa Álava (Spain). 

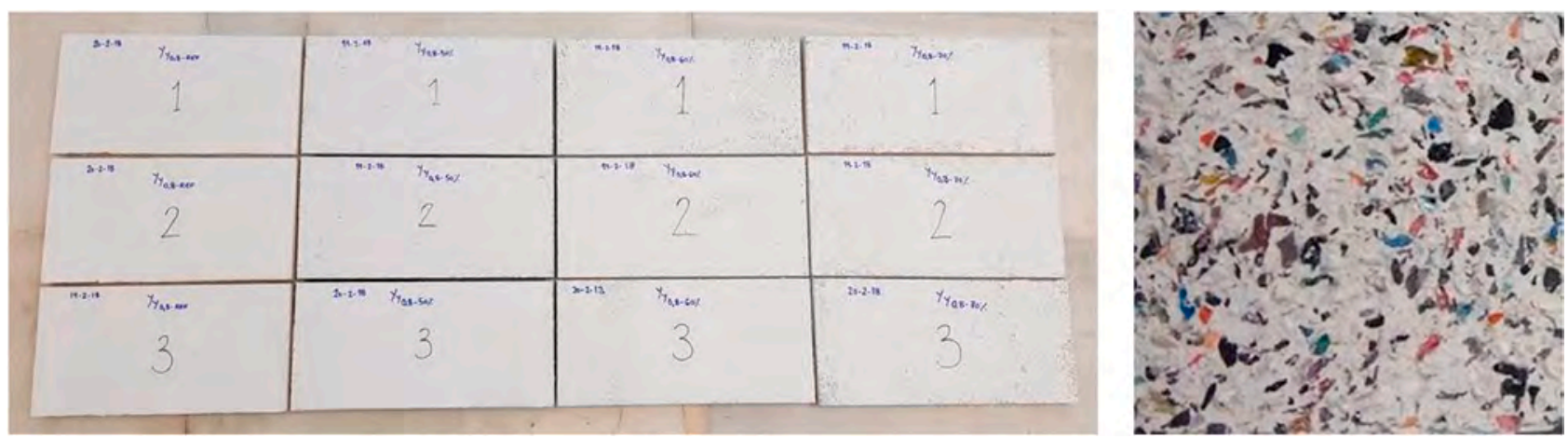

Fig. 2. (Left) batches of plasterboard and PR panels. (Right) panel section.

\subsection{Experimental plan}

For the analysis of the behavior of the components in response to a fire, direct, non-standardized real fire testing was conducted, as well as an estimation of the gases released from the combustion of the components.

\subsubsection{Direct real fire test}

To analyze the effect of the fire on the different components made, a non-standardized, real fire test was conducted in the Collado Villalba Fire Station, in the Community of Madrid (Spain). To carry out this direct fire resistance test, ISO standard R-834 [6] was considered, in which it is estimated that sixty minutes of heat stress in a construction fire is equivalent to the heat stress of $40 \mathrm{~kg}$ of pine wood per square meter $(\mathrm{kg} / \mathrm{m} 2)$.

The panels were placed on a grill situated inside a room that was previously prepared for the real fire tests. A thirty-minute test was prepared. Therefore, prior to the same, $20 \mathrm{~kg}$ of chopped pine wood were distributed over the grill. The panels were extended horizontally with one of their sides coming into direct contact with the fire, such that a sample of each component was present in each of the areas generated in the grill. That is, the area furthest from the fire (out), the interior area (ins) and the middle area (med). In this scheme, there are six panels situated in the rear part of the grill, and therefore in a place with heat containment due to the walls of the room; the other six panels are located in the front part of the grill, that is a place with less heat containment (Fig. 3).

Afterward, and in order to promote the combustion, approximately one liter of gasoline was sprayed on the wood and the set was lit. For the thirty minutes of the test (Fig. 4), temperature readings were carried out at three points of each test sample, every $5 \mathrm{~min}$, using a Testo 845 laser reader. Finally, the samples were allowed to slowly cool off.

\subsubsection{Bases for the theoretical estimate of the combustion gas composition}

For this, the existing bibliography in this area was consulted. In addition, an estimated calculation of the quantity of $\mathrm{CO}_{2}$ and $\mathrm{CO}$ emitted was performed, based on the chemical decomposition of the PR, according to the results obtained in the thermogravimetric test and elemental analysis, conducted in a prior study and presented in Tables 2 and 3 [2,31]. Based on this calculation, an approximation was made of the quantity of $\mathrm{CO}$ and $\mathrm{CO}_{2}$ emitted by the compounds in a room suffering from a real fire (Fig. 5).

\section{Results and discussion}

\subsection{Behavior in response to a real fire}

The mean data obtained from the three temperature readings of each of the panels is shown in Table 4. The environmental temperature at the time of the test onset was $3.6^{\circ} \mathrm{C}$ and at $5 \mathrm{~min}$ of exposure to the fire, all of the compounds exceeded $200^{\circ} \mathrm{C}$. In general, maximum temperatures were reached between 5 and $10 \mathrm{~min}$ of exposure for all of the compounds, except for the compound containing $50 \%$ waste, which reached its maximum after 15-20 min.

First, the panels placed in the exterior position with distinct composition were analyzed (Fig. 6-A). At $10 \mathrm{~min}$ of test onset, the reference compound and the compound consisting of $70 \%$ waste had reached the maximum peak temperature, which was approximately $600^{\circ} \mathrm{C}$. Over the following $5 \mathrm{~min}$, and in a brusque manner, they began their cooling process, until reaching $330^{\circ} \mathrm{C}$, which finalized at $260^{\circ} \mathrm{C}$, some $30 \mathrm{~min}$ after the onset of the fire. Compounds containing $50 \%$ and $60 \%$ waste had a distinct behavior, with a maximum temperature peak being reached at $5 \mathrm{~min}$ of the trial onset and not exceeding $370^{\circ} \mathrm{C}$. Their cooling process was more gradual until reaching $180^{\circ} \mathrm{C}$ and $265^{\circ} \mathrm{C}$, respectively, at the end of the test period.

The panel placed in the external area having the best fire behavior in

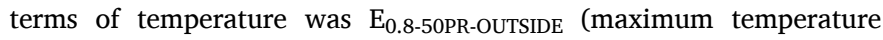
reached of $369.00^{\circ} \mathrm{C}$ at $5 \mathrm{~min}$ and final temperature of $178.67^{\circ} \mathrm{C}$ ). The worst behavior was that of $\mathrm{E}_{0.8-70 \mathrm{PR}-\mathrm{OUTSIDE}}$ (maximum temperature of $597.00^{\circ} \mathrm{C}$ reached at $10 \mathrm{~min}$ and final temperature of $267.33^{\circ} \mathrm{C}$ ).

Next, all of the panels placed in the middle position were analyzed (Fig. 6-B). In this case, the panels consisting of 50\% and $60 \%$ waste reached a maximum peak temperature of $600^{\circ} \mathrm{C}$ some $10 \mathrm{~min}$ after test onset. During the next $5 \mathrm{~min}$, their temperature decreased to

\begin{tabular}{|c|c|c|c|c|c|}
\hline $\begin{array}{c}\text { E0,8_1 } \\
\text { (out) } \\
\text { Rear }\end{array}$ & $\begin{array}{c}\text { E0,8- } \\
\text { 60PR_3 } \\
\text { (med) } \\
\text { Rear }\end{array}$ & $\begin{array}{c}\text { E0,8- } \\
\text { 70PR_3 } \\
\text { (ins) } \\
\text { Rear }\end{array}$ & $\begin{array}{c}\text { E0,8_2 } \\
\text { (ins) } \\
\text { Rear }\end{array}$ & $\begin{array}{c}\text { E0,8- } \\
\text { 50PR_3 } \\
\text { (med) } \\
\text { Rear }\end{array}$ & $\begin{array}{c}\text { E0,8- } \\
\text { 70PR_2 } \\
\text { (out) } \\
\text { Rear }\end{array}$ \\
\hline $\begin{array}{c}\text { E0,8- } \\
\text { 60PR_2 } \\
\text { (out) } \\
\text { Front }\end{array}$ & $\begin{array}{c}\text { E0,8_3 } \\
\text { (med) } \\
\text { Front }\end{array}$ & $\begin{array}{c}\text { E0,8- } \\
\text { 60PR_1 } \\
\text { (ins) } \\
\text { Front }\end{array}$ & $\begin{array}{c}\text { E0,8- } \\
\text { 50PR_2 } \\
\text { (ins) } \\
\text { Front }\end{array}$ & $\begin{array}{c}\text { E0,8- } \\
\text { 70PR_1 } \\
\text { (med) } \\
\text { Front }\end{array}$ & $\begin{array}{c}\text { E0,8- } \\
\text { 50PR_1 } \\
\text { (out) } \\
\text { Front }\end{array}$ \\
\hline
\end{tabular}

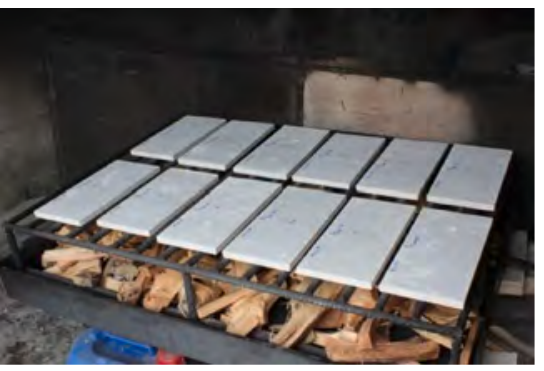

Fig. 3. Placement of the panels on the grill. Layout (left), reality (right). 

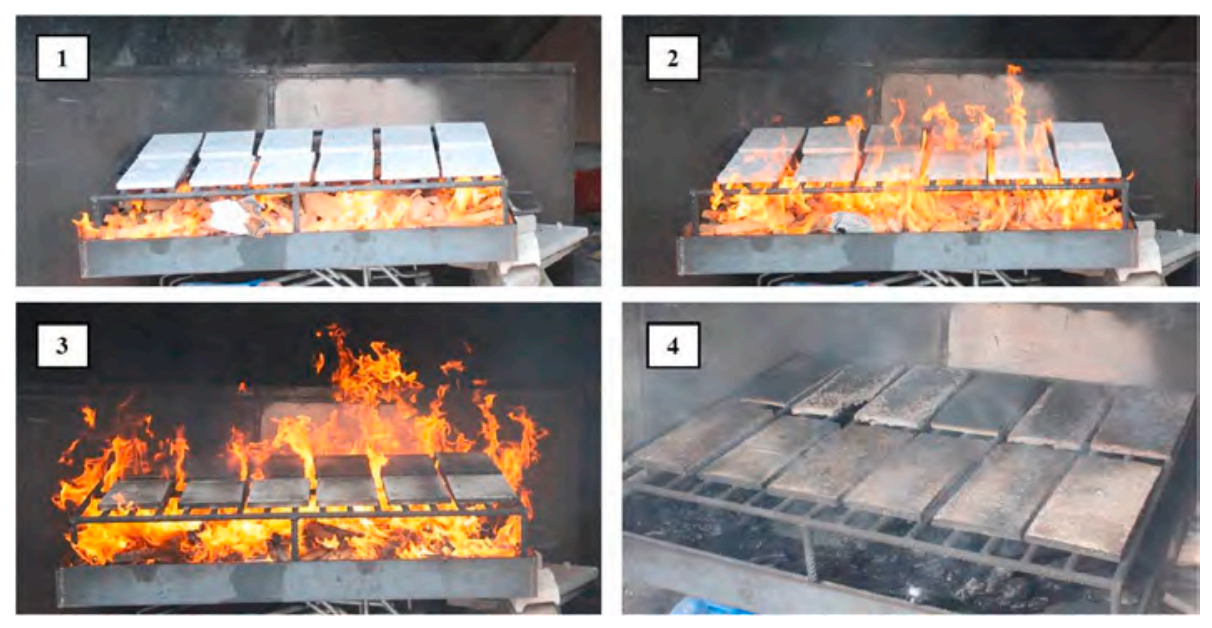

Fig. 4. Phases of the fire. 1- ignition; 2- latent fire; 3- heating; 4- cooling.

Table 2

Loss of mass of samples in thermogravimetric analysis.

\begin{tabular}{lllll}
\hline $\begin{array}{l}\text { Raw } \\
\text { Material }\end{array}$ & $\begin{array}{l}<100^{\circ} \mathrm{C} \\
(\%)\end{array}$ & $\begin{array}{l}100^{\circ} \mathrm{C}-200^{\circ} \mathrm{C} \\
(\%)\end{array}$ & $550^{\circ} \mathrm{C}-800^{\circ} \mathrm{C}(\%)$ & $\begin{array}{l}\text { Total } \\
(\%)\end{array}$ \\
\hline Gypsum & 1 & 5.8 & 0.8 & 7.7 \\
\hline & $\begin{array}{l}<350 / 375^{\circ} \mathrm{C} \\
(\%)\end{array}$ & $\begin{array}{l}350 / 375-700^{\circ} \mathrm{C} \\
(\%)\end{array}$ & $\begin{array}{l}\text { Total } \\
(\%)\end{array}$ \\
\hline PR & 20.6 & 59.3 & $81.4 \%$ \\
\hline
\end{tabular}

Table 3

Elemental analysis of samples (concentration greater than $0.5 \%$ ).

\begin{tabular}{llll}
\hline Compound/Element & Gypsum (\%) & Compound/Element & PR (\%) \\
\hline Calcium sulfate & $99.70 \%$ & Organic material & $77.20 \%$ \\
Aluminum & $0.022 \%$ & Bromine & $3.300 \%$ \\
Iron & $0.035 \%$ & Calcium & $1.470 \%$ \\
Match & $0.010 \%$ & Chlorine & $3.350 \%$ \\
Silicon & $0.068 \%$ & Copper & $4.330 \%$ \\
Strontium & $0.157 \%$ & Iron & $0.520 \%$ \\
& & Magnesium & $0.176 \%$ \\
& & Lead & $1.350 \%$ \\
& & Sulfur & $0.041 \%$ \\
& & Antimony & $7.080 \%$ \\
& & Silicon & $0.467 \%$ \\
& & Titanium & $0.314 \%$ \\
& & Zinc & $0.443 \%$ \\
\hline
\end{tabular}

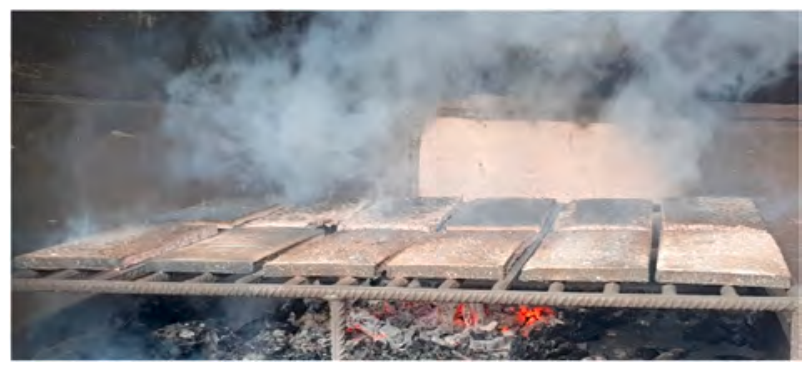

Fig. 5. Gas emission from plasterboard panels subjected to a real fire.

approximately $460{ }^{\circ} \mathrm{C}$ although $5 \mathrm{~min}$ later, it returned to $600^{\circ} \mathrm{C}$ in the case of the $50 \%$ waste panels and $535{ }^{\circ} \mathrm{C}$ for the $60 \%$ waste panels. At the end of the $30-\mathrm{min}$ test, their temperature was $320^{\circ} \mathrm{C}$. On the other hand, the reference compound and the compound with $70 \%$ waste had a maximum peak temperature at $5 \mathrm{~min}$ following the test onset, and did not reach $390^{\circ} \mathrm{C}$; then, the temperature began to gradually lower until reaching $217^{\circ} \mathrm{C}$ at the end of the test.

The best fire behavior, in terms of temperature, of the panels situated in the middle area, was that of $\mathrm{E}_{0.8-70 \mathrm{PR}-\mathrm{MIDDLE}}$ (maximum temperature reached of $389.33^{\circ} \mathrm{C}$ at $5 \mathrm{~min}$ and, at the end of the test, $216.33^{\circ} \mathrm{C}$ ). The worst behavior was that of $\mathrm{E}_{0.8-60 \mathrm{PR}-\mathrm{MIDDLE}}$ (maximum temperature of $603.33{ }^{\circ} \mathrm{C}$ reached at $10 \mathrm{~min}$ and, at the end of the test, $318.00^{\circ} \mathrm{C}$ ).

Third, the panels situated in the interior area were analyzed (Fig. 6C). The reference compound and the compound with $70 \%$ waste reached a maximum peak temperature of over $600{ }^{\circ} \mathrm{C}$ in both cases $\left(603.33^{\circ} \mathrm{C}\right.$ and $665.33^{\circ} \mathrm{C}$, respectively) at $10 \mathrm{~min}$. Then, the cooling process for the $70 \%$ waste compound panels began gradually, until $20 \mathrm{~min}$ had passed, at which point it increased over the final $10 \mathrm{~min}$, reaching $260^{\circ} \mathrm{C}$ by the end of the test. However, the reference compound experienced a harsh temperature decrease some $15 \mathrm{~min}$ before test completion, until gradually ending at $335^{\circ} \mathrm{C}$. The compound containing $50 \%$ waste had a maximum peak temperature at $15 \mathrm{~min}$, and then gradually began its temperature descent until reaching $270^{\circ} \mathrm{C}$ upon the test's completion. The compound made up of $60 \%$ waste reached its maximum peak temperature at $5 \mathrm{~min}$, reaching $300^{\circ} \mathrm{C}$, then decreasing during the following $5 \mathrm{~min}$ to reach $180^{\circ} \mathrm{C}$ and, then, once again began to increase until reaching $265^{\circ} \mathrm{C}$ at the end of the test.

The panel located in the lower area that displayed the best fire behavior, in terms of temperature, was $\mathrm{E}_{0.8 \text {-60PR-INTERIOR (maximum }}$ temperature of $298.33^{\circ} \mathrm{C}$ reached at $5 \mathrm{~min}$ and, at the end of the test, $266.33^{\circ} \mathrm{C}$ ). The panel with the poorest behavior was $\mathrm{E}_{0.8-70 \text { PR-INTERIOR }}$ (maximum temperature of $628.33^{\circ} \mathrm{C}$ reached at $5 \mathrm{~min}$ and, at the end of the test, $334.33^{\circ} \mathrm{C}$ ).

The behavior between panels having the same compound but different positions was also analyzed (Fig. 7). It can be observed that the panels of the reference compound behaved similarly to the panels with the compound with $70 \% \mathrm{PR}$, that is, the panel placed in an interior position is that which reaches the highest temperature, slightly surpassing $600^{\circ} \mathrm{C}$. On the other hand, the middle position panel reaches the lowest temperature, not higher than $390^{\circ} \mathrm{C}$. The panels located in the exterior position, contrary to expectations, also reached temperatures of almost $600{ }^{\circ} \mathrm{C}$. As for compounds with 50\% PR and 60\% PR, their panels behaved similarly. In this case, the panel placed in the middle position was the one to reach the highest temperature, approximately $600^{\circ} \mathrm{C}$; the panel placed in the interior position reached the lowest temperature, not exceeding $330^{\circ} \mathrm{C}$ and; finally, the panel placed in the exterior position reached temperatures that were slightly higher than those of the interior panel, approaching $370{ }^{\circ} \mathrm{C}$.

In general, the panel revealing the best fire behavior, in terms of temperature, was $\mathrm{E}_{0.8-60 \mathrm{PR}-\mathrm{INTERIOR} \text { (maximum temperature reached was }}$ $298,33^{\circ} \mathrm{C}$, at $\left.5 \mathrm{~min}\right)$. The panel with the poorest behavior was $\mathrm{E}_{0,8-70 \mathrm{PR} \text { - }}$ 
Table 4

Average temperature of the panels during the real fire test.

\begin{tabular}{|c|c|c|c|c|c|c|c|}
\hline \multirow[t]{2}{*}{ Panel } & $\mathrm{T}\left({ }^{\circ} \mathrm{C}\right)$ & $\mathrm{T}\left({ }^{\circ} \mathrm{C}\right)$ & $\mathrm{T}\left({ }^{\circ} \mathrm{C}\right)$ & $\mathrm{T}\left({ }^{\circ} \mathrm{C}\right)$ & $\mathrm{T}\left({ }^{\circ} \mathrm{C}\right)$ & $\mathrm{T}\left({ }^{\circ} \mathrm{C}\right)$ & $\mathrm{T}\left({ }^{\circ} \mathrm{C}\right)$ \\
\hline & $0 \mathrm{~min}$ & $5 \mathrm{~min}$ & $10 \mathrm{~min}$ & $15 \mathrm{~min}$ & $20 \mathrm{~min}$ & $25 \mathrm{~min}$ & $30 \mathrm{~min}$ \\
\hline $\mathrm{E}_{0.8 \text {-OUTSIDE }}$ & 3.60 & 443.33 & 602.67 & 328.00 & 301.67 & 281.00 & 236.33 \\
\hline $\mathrm{E}_{0.8-50 P R-O U T S I D E}$ & 3.60 & 369.00 & 231.67 & 174.33 & 176.33 & 166.33 & 178.67 \\
\hline $\mathrm{E}_{0.8 \text {-60PR-OUTSIDE }}$ & 3.60 & 366.67 & 292.33 & 211.00 & 248.00 & 299.00 & 264.67 \\
\hline $\mathrm{E}_{0.8 \text {-70PR-OUTSIDE }}$ & 3.60 & 501.33 & 597.00 & 315.67 & 250.67 & 258.33 & 267.33 \\
\hline $\mathrm{E}_{0.8 \text {-MEDIUM }}$ & 3.60 & 354.00 & 229.00 & 269.33 & 248.67 & 264.00 & 217.00 \\
\hline $\mathrm{E}_{0.8-50 P R-M E D I U M}$ & 3.60 & 450.67 & 596.67 & 433.33 & 600.00 & 352.67 & 311.00 \\
\hline $\mathrm{E}_{0.8-60 \mathrm{PR}-\mathrm{MEDIUM}}$ & 3.60 & 531.67 & 603.33 & 479.33 & 533.33 & 359.67 & 318.00 \\
\hline $\mathrm{E}_{\text {0.8-70PR-MEDIUM }}$ & 3.60 & 389.33 & 240.33 & 238.33 & 220.00 & 224.00 & 216.33 \\
\hline $\mathrm{E}_{0.8 \text {-INSIDE }}$ & 3.60 & 567.00 & 603.33 & 344.67 & 333.00 & 308.00 & 260.33 \\
\hline $\mathrm{E}_{0.8-50 \mathrm{PR} \text {-INSIDE }}$ & 3.60 & 232.67 & 212.33 & 325.30 & 303.33 & 234.33 & 270.67 \\
\hline $\mathrm{E}_{0.8-60 \mathrm{PR}-\mathrm{INSIDE}}$ & 3.60 & 298.33 & 179.33 & 269.67 & 229.33 & 276.67 & 266.33 \\
\hline $\mathrm{E}_{0.8-70 \mathrm{PR} \text {-INSIDE }}$ & 3.60 & 628.33 & 665.33 & 600.00 & 596.67 & 378.00 & 334.33 \\
\hline
\end{tabular}
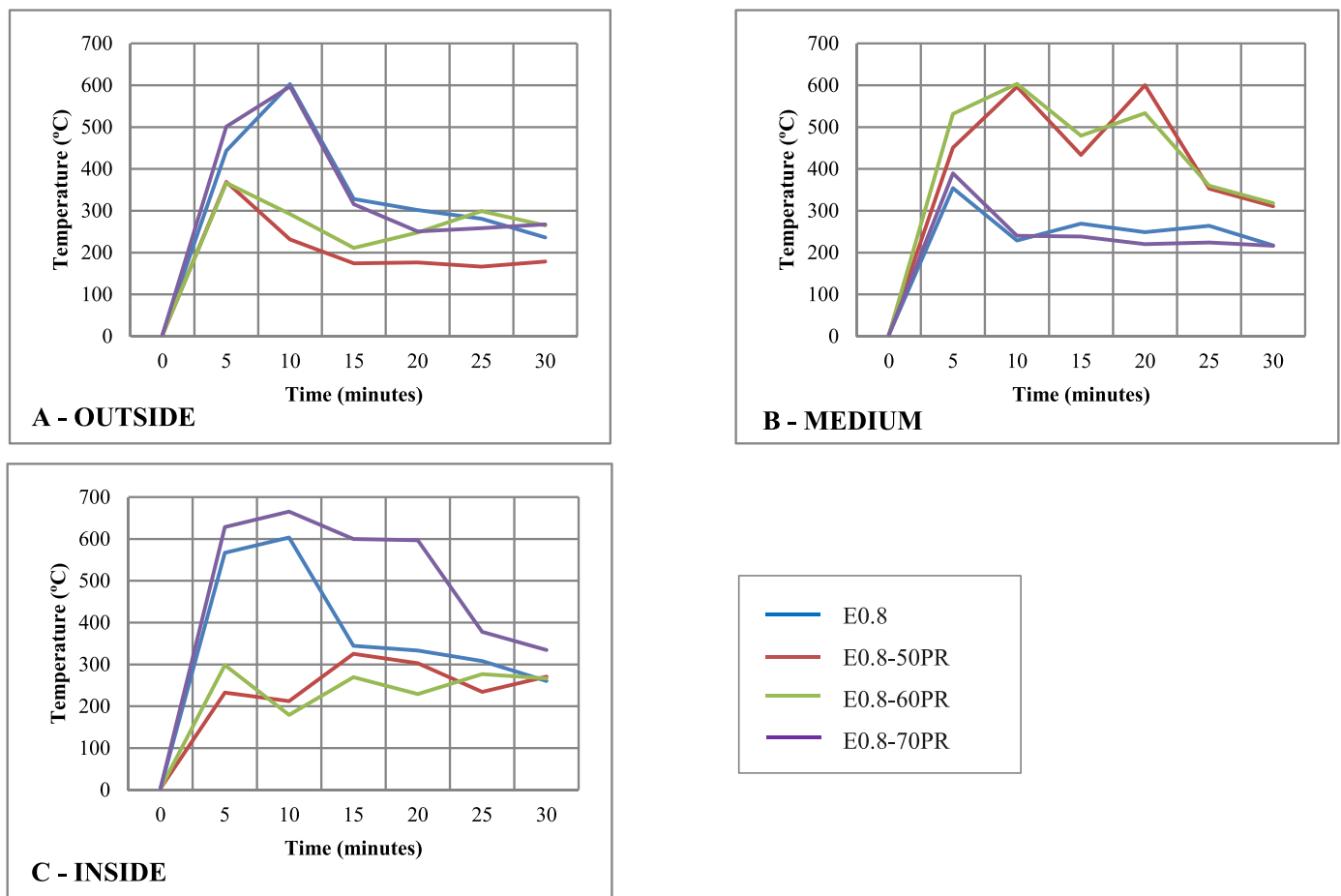

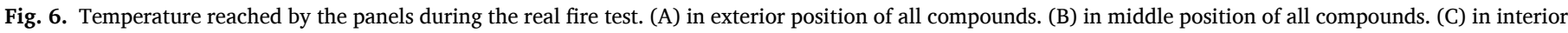
position of all compounds.

INTERIOR (maximum temperature reached of $628.33^{\circ} \mathrm{C}$ at $5 \mathrm{~min}$ ).

In addition, it was observed that the behavior of the specimens located in the rear part of the grill, with more heat containment, was similar between them, in terms of temperature range and durability over time (Fig. 8A). The temperature reached exceeded $600^{\circ} \mathrm{C}$ in all the specimens and their cooling was slower, gradually decreasing over time.

The behavior of the specimens located in the front part of the grill, with less heat containment, was also similar, but different from the previous ones (Fig. 8B). In this area, the temperature of the specimens did not reach $400{ }^{\circ} \mathrm{C}$ and their cooling began $5 \mathrm{~min}$ after the fire started, the temperature remaining practically uniform from $10 \mathrm{~min}$ until the end of the test.

Overall, all of the tested panels had a charred external appearance (Fig. 9); however, the interior of the reference panels (without waste) was unaltered, due to its non-flammability, while the interior of the panels with waste displayed a multitude of voids, due to the disappearance of the polymers following their fusion and combustion (Fig. 10). According to the previous study in which thermogravimetric analysis was performed on the waste included in the plasterboard, the fusion of the polymeric waste took place at an approximate temperature of $200{ }^{\circ} \mathrm{C}$, and at approximately $500^{\circ} \mathrm{C}$, its thermal-oxidative decomposition in air was complete [2,31]. The decomposition of the waste led to a series of cavities in the panel mass, which weakened the connection of the gypsum particles. The reference panels became more fragile and broke during the test, while the panels with waste, in addition to breaking, easily disintegrated.

It should be noted that in the bibliography considering plasterboard panels with aggregate plastics, when standardized combustibility tests were carried out, a relationship was observed between the quantity of polymers and the velocity and onset of combustion, with a larger proportion of polymers increasing combustion speed and accelerating the onset of the same [32,33]. In the real fire test performed in this work, no clear tendency has been observed between the quantity of the polymer of the panel and the temperature-time profile. However, it is evident that the presence of gypsum acts as a retardant of the combustion processes for the polymeric waste found in the panels as compared to the 

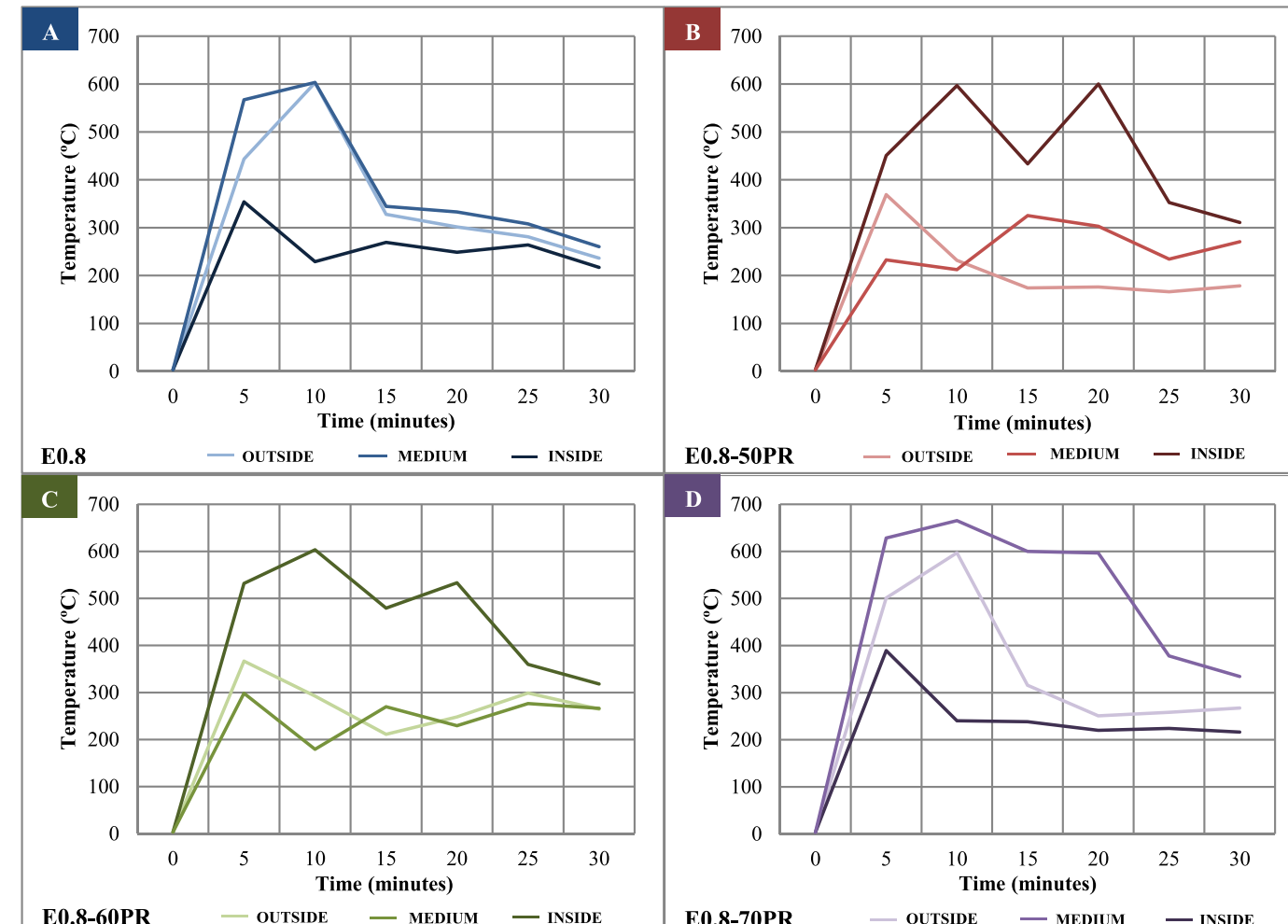

Fig. 7. Temperature reached by the panels during the real fire test. A: $\mathrm{E}_{0.8} ; \mathrm{B}: \mathrm{E}_{0.8-50 \mathrm{PR}} ; \mathrm{C}: \mathrm{E}_{0.8-60 \mathrm{PR}} ; \mathrm{D}: \mathrm{E}_{0.8-70 \mathrm{PR}}$.
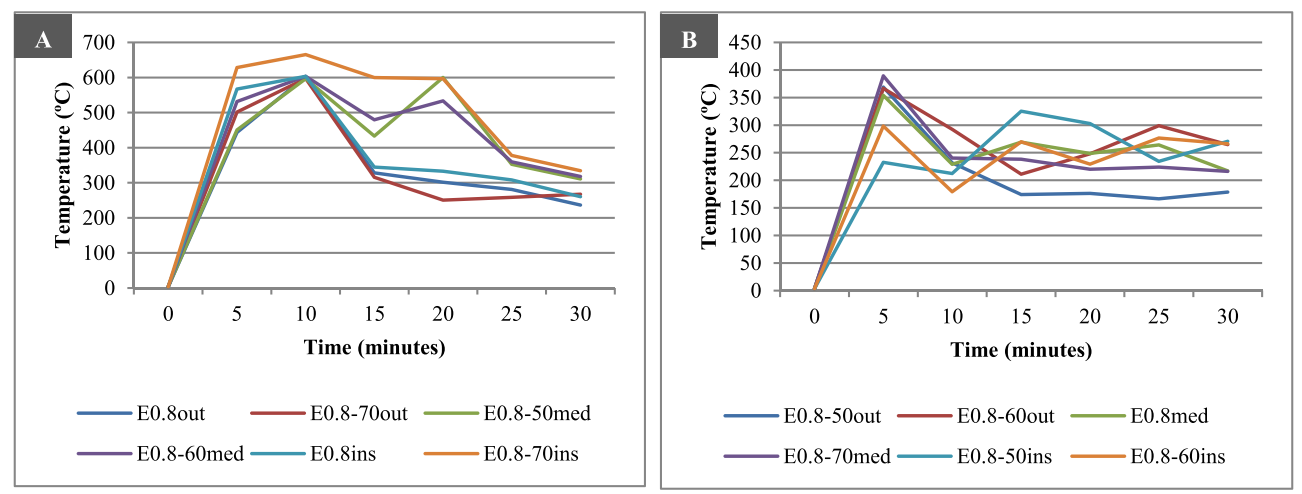

Fig. 8. Temperature behavior in the zone with more heat containment (A) and with less heat containment (B).

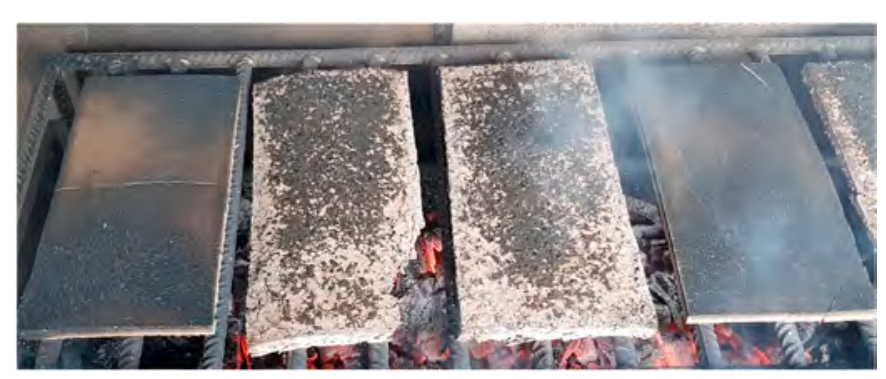

Fig. 9. Exterior appearance of the panels at the end of the real fire test. Endsreference panels. Center- panels with waste.

polymeric materials that were completely exposed. The inflammable nature of the plaster protects the polymeric waste for some time, especially during the ignition phase, offering additional time for user evacuation.

\subsection{Theoretical estimate of the combustion gas composition}

For the calculations made in this section, the analytic results obtained for the PR following the thermogravimetric analysis in the air were considered, as well as the results obtained in the elemental analysis $[2,31]$.

Based on these results, it was found that PR lost $84 \%$ of their mass and their decomposition process took place at the $200-500{ }^{\circ} \mathrm{C}$ range. Given the temperatures reached in the fire test, which exceeded $600^{\circ} \mathrm{C}$, and because temperatures in a fire tend to reach between $800^{\circ} \mathrm{C}$ and $1200{ }^{\circ} \mathrm{C}[1]$, it is quite likely that the pellet decomposition processes will be completed after reaching any of these temperatures. Some $16 \%$ of the remaining PR appear in the form of ash, which, according to the bibliography, consists of oxides of elements found in the polymers (aluminum, silicon or alkaline metals), heavy metals of low volatility and residual carbon materials [8]. As for the elemental analysis of the $\mathrm{PR}$, which contains $\mathrm{Si}$ and $\mathrm{Ca}$, silicon oxide and calcium oxide may be found in the ash. 

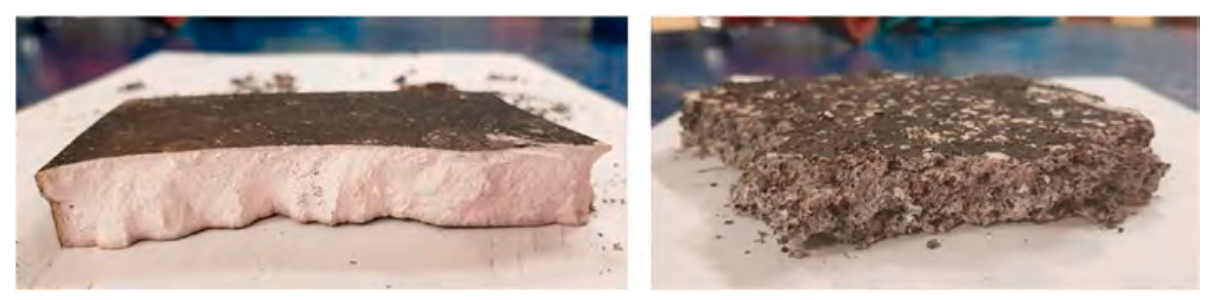

Fig. 10. Interior appearance of the panels at the end of the real fire test. Left- reference panel. Right- panel with waste.

This lost mass of some $84 \%$ of the PR may include both the combustion of the carbon material (organic) as well as the formation of compounds derived from the volatile metals; once again considering the elemental composition of the PR, which may produce volatile oxides of $\mathrm{Pb}$ and $\mathrm{Sb}$. The presence of chlorine in the pellet would favor the formation of other volatile compounds, such as, for example, $\mathrm{Pb}$ or $\mathrm{Zn}$ chloride. In addition, acid gases may be generated, such as $\mathrm{HCl}$ and $\mathrm{SO}_{2}$, due to the mentioned presence of chloride and the presence of sulfur. Besides, many other toxic compounds may also arise, as mentioned in the thorough literature review conducted by Aracil Saez on the combustion of organic material [8]. The formation of these compounds depends not only on the material, but also on other factors, such as, for example, the concentration of oxygen present and the temperatures reached.

However, organic material is the main constituent of the PR, with $77.2 \%$ based on elemental analysis, therefore its thermal and oxidative decomposition is the main source of gas emissions derived from PR combustion in the tested panels, with $\mathrm{CO}$ being the most important compound in terms of emissions produced in fires. On the other hand, plaster only loses water at low temperatures, close to $100{ }^{\circ} \mathrm{C}(9 \%$ based on the thermogravimetric analysis), becoming anhydrous calcium sulfate, hence considered to be non-flammable. Its presence as an envelope for PR in the panels serves as a physical barrier that may delay pellet combustion and prevent the emission of combustion gases, as compared to other polymeric materials exposed to fire that may be present in a room having no sort of physical protection. In the elemental analysis, the use of flame retardants has been highlighted in polymer formulation, since the presence of bromine and antimony have been detected, both of which increase the duration of the latent fire phase, prior to the flashpoint $[34,35]$.

Based on the composition of the compounds, the quantity of $\mathrm{CO}_{2}$ and $\mathrm{CO}$ generated by the combustion of $1 \mathrm{~kg}$ of PR was calculated, taking the following information into consideration:

- Based on the thermogravimetric analysis, $0.84 \mathrm{~kg}$ of PR are burned, with the rest of the mass becoming ash.

- It is considered that the pellet contains two types of polymers, vinyl polychloride (PVC) and polyethylene (PE), since these are the most abundant in this type of waste [36].

- The quantity of PVC in the PR is calculated, assigning all of the chloride present in the PR to the PVC, 3.35\% according to the elemental analysis. The following general formula is considered for PVC: $\left(\mathrm{CH}_{2}-\mathrm{CHCl}\right) n$-, that is, $\left(\mathrm{C}_{2} \mathrm{H}_{3} \mathrm{Cl}\right) n$. It is considered that the rest of the combustible material in the PR would be made up of $\mathrm{PE}$, whose general formula is: $\left(\mathrm{CH}_{2}-\mathrm{CH}_{2}\right) n$-, that is, $\left(\mathrm{C}_{2} \mathrm{H}_{4}\right) \mathrm{n}$.

- Upon determining the quantity of each of the polymers, the quantity of $\mathrm{CO}_{2}$ emitted in the completed PR combustion is calculated. If the combustion was incomplete, carbon monoxide (CO) may be generated, but since both dioxide and monoxide contain a carbon atom, the number of moles of both of these would be identical.

Based on this working hypothesis, results suggest that in the complete combustion of $1 \mathrm{~kg}$ of PR pellet, a total of $2.53 \mathrm{~kg} \mathrm{CO}_{2}(8,3$. $10^{-2} \mathrm{~kg} \mathrm{CO}_{2}$ of PVC $+2,45 \mathrm{~kg} \mathrm{CO}_{2}$ of PE) are emitted. If the combustion was incomplete, a total of $1.61 \mathrm{~kg}$ CO $\left(5,28 \cdot 10^{-2} \mathrm{~kg} \mathrm{CO}\right.$ of PVC $+1,56$ $\mathrm{kg}$ CO of PE) would be emitted.

Having obtained the possible $\mathrm{CO}_{2}$ and $\mathrm{CO}$ for each $\mathrm{kg}$ of $\mathrm{PR}$, it is important to be able to compare it with the quantity that is estimated as being hazardous for the health of the individuals. For this, a calculation was carried out of the combustion gases generated in a $4 \mathrm{~m} \times 3 \mathrm{~m} \times 2.6 \mathrm{~m}$ room in which the partitions are made of standard panels of the studied compounds $\left(2000 \times 1200 \times 12,5 \mathrm{~mm}^{3}\right)$. Results are shown in Table 5 .

The main effect of $\mathrm{CO}_{2}$ is suffocation caused by oxygen displacement, but this takes place in very high concentrations exceeding 30,000 ppm [37]. In the results obtained, considering a complete combustion of the panels of a room of the proposed type, it may be observed that the concentration of $\mathrm{CO}_{2}$ generated by the PR compounds would not exceed this quantity. Therefore, a priori, the panels studied do not act as a risk to the health of individuals exposed to a fire in a property that chooses to use this type of panels in its construction.

In terms of $\mathrm{CO}$, the values obtained are high and exceed the maximum limits considered dangerous to health, considering that with $6400 \mathrm{ppm}$ loss of consciousness and risk of death can occur within 10-15 min [38]. However, in this case of incomplete combustion of the panel considered in the type of room proposed, it must be taken into account that organic material, both synthetic (for example, polymeric materials) and natural (for example, wood), would lead to high concentrations of carbon monoxide in a fire, which exceed the limits dangerous to health, as in any uncontrolled fire in which $\mathrm{CO}$ is produced as a by-product. The $\mathrm{CO}$ values that have been calculated are extreme since it is considered that $\mathrm{CO}_{2}$ has not been formed. Other factors to take into account are those referred to in the Firefighters Manuals studied by firefighters during their training, in which it is stated that, in recent years, the massive incorporation of synthetic materials in the manufacture of furniture and household items has had a greater impact on the development of interior fires, since their calorific value far exceeds that of traditional fuels with faster development curves. To this must be added the increase in furniture found in today's homes, a larger surface area and a higher degree of thermal insulation [39]. Therefore, all these synthetic materials found within a room can emit CO during a fire, potentially earlier than the composite panels under study, whose emissions can be delayed thanks to the physical barrier produced by gypsum.

\section{Conclusions}

In this study has been verified that, in a real fire, there is no clear tendency between the evolution of temperatures with time and the quantity of plastic cable waste added. Similar results were observed between the reference and the compound containing 70\% PR and between that of $50 \%$ PR and that of $60 \%$ PR. The difference observed in the behavior of the specimens has been in relation to the surroundings, reaching a higher temperature (up to $600^{\circ} \mathrm{C}$ ) and a slower cooling if they are located in places with greater heat containment, than in places with less containment (up to $400^{\circ} \mathrm{C}$ ) in which the cooling begins earlier and remains uniform after $10 \mathrm{~min}$ of the onset of fire. In all of the compounds, the maximum temperatures are reached at 5-10 $\mathrm{min}$ of the onset of the fire.

It has also been observed that the plaster's non-flammability contributes to the improved behavior of plastic waste in the face of a fire, offering a physical mechanism of action that facilitates user evacuation. 
Table 5

Quantity of $\mathrm{CO}_{2}$ and CO issued in the PR combustion of the compounds in a proposed room of $12 \mathrm{~m}^{2}$ and $2.6 \mathrm{~m}$ height (volume $31.2 \mathrm{~m}$ ).

\begin{tabular}{|c|c|c|c|c|c|c|}
\hline Panel & $\begin{array}{l}\text { Quantity of PR per panel } \\
\text { (Kg/unit) }\end{array}$ & $\begin{array}{l}\text { Estimated quantity of panels in a } \\
\text { type of room (unit) }\end{array}$ & $\begin{array}{l}\text { Total PR in the proposed } \\
\text { room }(\mathrm{Kg})\end{array}$ & $\begin{array}{l}\mathrm{CO}_{2} / \mathrm{CO} \text { issued } \\
(\mathrm{Kg})\end{array}$ & $\begin{array}{l}\mathrm{CO}_{2} / \mathrm{CO} \text { issued by unit of } \\
\text { volume }\left(\mathrm{Kg} / \mathrm{m}^{3}\right)\end{array}$ & $\begin{array}{l}\mathrm{CO}_{2} / \mathrm{CO} \text { issued } \\
(\mathrm{ppm})\end{array}$ \\
\hline $\mathrm{E}_{0.8}$ & 0.00 & 15 & 0.00 & 0.00 & 0.00 & 0.00 \\
\hline $\begin{array}{c}E_{0.8-} \\
50 P R\end{array}$ & 10.49 & 15 & 157.35 & $398.10 / 253.33$ & $12.76 / 8.12$ & $12,760 / 8120$ \\
\hline $\begin{array}{l}\mathrm{E}_{0.8-} \\
\quad 60 \mathrm{PR}\end{array}$ & 11.72 & 15 & 175.80 & $444.77 / 283.04$ & $14.26 / 9.07$ & $14,260 / 9070$ \\
\hline $\begin{array}{l}\mathrm{E}_{0.8-} \\
\quad 70 \mathrm{PR}\end{array}$ & 13.67 & 15 & 205.05 & $518.78 / 330.13$ & $16.63 / 10.58$ & $16,630 / 10,580$ \\
\hline
\end{tabular}

Its presence serves as an envelope for plastic cable waste in the panels, acting as a physical barrier that delays the combustion of the pellets and hinders the emission of the combustion gases, as compared to other polymeric materials exposed to fire that may be present in a room and having no physical protection.

Regarding the combustion gases emitted during a fire in a room, the theoretical calculus has been centered in the concentrations of carbon dioxide $\left(\mathrm{CO}_{2}\right)$ and carbon monoxide (CO) that would be generated, considering the plastic cable waste composed of PVC and PE. In the hypothesis made, it has been obtained that the amount of $\mathrm{CO}_{2}$ generated after a fire would not pose a risk to people's health, since it does not exceed the maximum limits established in the regulations. On the other hand, the values obtained for the generation of $\mathrm{CO}$ in the hypothesis exceed the maximums considered dangerous to health. However, the plastic cable waste, as it is seen in the chemical analysis, also contains other additives and compounds that can potentially produce dangerous contaminants in the combustion, and an empirical study should be conducted in order to monitor and analyses the composition of combustion gases.

With the manufacturing of the compounds in this study, the quantity of plastic cable waste in landfills is reduced as well as the incineration to which this waste is subjected as a means of elimination after obtaining the metal from the central thread, avoiding the risk of atmospheric contaminant discharge and contributing to our planet's sustainability.

\section{CRediT authorship contribution statement}

Alejandra Vidales-Barriguete: Conceptualization, Data curation, Formal analysis, Investigation, Methodology, Software, Supervision, Validation, Visualization, Writing - original draft, Writing - review \& editing. Carolina Piña-Ramírez: Conceptualization, Data curation, Formal analysis, Investigation, Visualization. Rubén Serrano-Somolinos: Conceptualization, Data curation, Formal analysis, Investigation, Methodology, Resources, Software, Supervision, Visualization. Mercedes del Río-Merino: Validation, Visualization, Writing - original draft, Writing - review \& editing. Evangelina Atanes-Sánchez: Formal analysis, Investigation, Methodology, Supervision, Validation, Visualization, Writing - original draft, Writing - review \& editing.

\section{Declaration of competing interest}

The authors declare that they have no known competing financial interests or personal relationships that could have appeared to influence the work reported in this paper.

\section{Acknowledgments}

To the Madrid Fire Department located in Collado Villalba for providing their facilities and personnel to conduct the real direct fire testing.

\section{References}

[1] A. Peinado Moreno, Manual S.E.P.E.I de Bomberos. Cursos de Iniciación y Reciclaje, Diputación de Albacete, Albacete (España), 2003. http://www.dipualba. es/Publicaciones/LibrosPapel/LibrosRed/Actuales/Libros/SEPEI.pdf.

[2] A. Vidales Barriguete, Caracterización fisicoquímica y aplicaciones de yeso con adición de residuo plástico de cables mediante criterios de economía circular, Tesis Doctoral, Universidad Politécnica de Madrid (España), 2019, https://doi.org/ 10.20868/UPM.thesis.57437.

[3] PlasticsEurope, Los plásticos y la seguridad contra incendios en el sector de la construcción, 2017, p. 20. https://www.plasticseurope.org/es/resources/publicati ons/319-los-plasticos-y-la-seguridad-contra-incendios-en-el-sector-de-la-construcci on. (Accessed 25 August 2019).

[4] Ministerio de Ciencia y Tecnología, Real Decreto 842/2002, de 2 de agosto, por el que se aprueba el Reglamento electrotécnico para baja tensión, 2002.

[5] Parlamento Europeo y Consejo de la Unión Europea, Reglamento 305/2011 por el que se establecen condiciones armonizadas para la comercialización de productos de construcción, D. Of. La Unión Eur., 2011, pp. 5-43. https://www.boe.es/d oue/2011/088/L00005-00043.pdf.

[6] ISO 834, Fire resistance tests, Elem. Build. Construct. (2014).

[7] R. Serrano, A. Cobo, M.I. Prieto, M. de las N. González, Analysis of fire resistance of concrete with polypropylene or steel fibers, Construct. Build. Mater. 122 (2016) 302-309, https://doi.org/10.1016/j.conbuildmat.2016.06.055.

[8] I. Aracil Sáez, Formación de contaminantes y estudio cinético en la pirólisis y combustión de plásticos (PE, PVC y PCP), Tesis Doctoral, Universidad de Alicante (España), 2008, 978-84-691-6015-2.

[9] J. Téllez, A. Rodríguez, Á. Fajardo, Contaminación por monóxido de carbono: un problema de salud ambiental, Rev. Salud Pública. 8 (2006) 108-117, https://doi. org/10.1590/S0124-00642006000100010.

[10] Instituto Nacional de Seguridad e Higiene en el Trabajo, NTP 549 El dióxido de carbono en la evaluación de la calidad del aire interior, 2000, pp. 1-6.

[11] P.T. Williams, Pollutants from incineration: an overview, in: R.M. Harrison, R. E. Hester (Eds.), Waste Inciner. Environ., 1994, pp. 27-52, https://doi.org/ 10.1039/9781847552327.

[12] J. Moltó, R. Font, A. Gálvez, J.A. Conesa, Pyrolysis and combustion of electronic wastes, J. Anal. Appl. Pyrolysis 84 (2009) 68-78, https://doi.org/10.1016/j. jaap.2008.10.023.

[13] R. Font, I. Aracil, A. Fullana, I. Martín-Gullón, J.A. Conesa, Semivolatile compounds in pyrolysis of polyethylene, J. Anal. Appl. Pyrolysis 68 (2003) 599-611, https://doi.org/10.1016/S0165-2370(03)00038-X.

[14] Ministerio de Agricultura Alimentación y Medio Ambiente, Real Decreto 815/ 2013, de 18 de octubre, por el que se aprueba el Reglamento de emisiones industriales y de desarrollo de la Ley 16/2002, de 1 de julio, de prevención y control integrados de la contaminación, 2013, p. 104. https://www.boe.es/boe/di as/2013/10/19/pdfs/BOE-A-2013-10949.pdf.

[15] N. Buezas Sierra, Guía: Plásticos y Fuego, 2010, p. 66. https://www.observatoriopl astico.com/ficheros/publicaciones/126155543Guia_plasticos_fuego_2010_encrip. pdf.

[16] L. Xian-hong, Study on the fire spread characteristics of plastic trash, Fire Sci. Technol. 3 (2017) 39.

[17] J. Goo, C.-H. Hwang, Measurement of the size distribution of smoke particles with plastic types under various fire conditions, Fire Sci. Eng. 31 (2017) 8-15, https:// doi.org/10.7731/KIFSE.2017.31.6.008.

[18] G. Xion, D. Zeng, A. Krisman, Y. Wang, On the burning behavior of thermoplastics at large scale: uncartoned unexpanded plastic commodity, Fire Saf. J. Mayo (2020) 103089, https://doi.org/10.1016/j.firesaf.2020.103089.

[19] Z. Kerekes, Á. Restás, É. Lublóy, The effects causing the burning of plastic coatings of fire-resistant cables and its consequences, J. Therm. Anal. Calorim. 139 (2020) 775-787, https://doi.org/10.1007/s10973-019-08526-9.

[20] F. Hernández-Olivares, G. Barluenga, Fire performance of recycled rubber-filled high-strength concrete, Cement Concr. Res. 34 (2004) 109-117.

[21] M. Mousavimehr, M. Nematzadeh, Predicting post-fire behavior of crumb rubber aggregate concrete, Construct. Build. Mater. 229 (2019) 116834, https://doi.org/ 10.1016/j.conbuildmat.2019.116834.

[22] E.R. Daniels, J. Newton, Gypsum Composites Used in Fire Resistant Building Components, 2016. US 9,375,899 B2, https://patents.google.com/patent/US937 5899B2/en.

[23] Q. Yu, W.D. Song, S. Veeramasuneni, W. LuanUAN, Low Weight and Density Fireresistant Gypsum Panel, 2018. https://patentimages.storage.googleapis.com/c6/ dd/f2/1a63f2672db866/EP2678290B1.pdf. 
[24] UNE-EN 13279-1:2009, Yesos de construcción y conglomerantes a base de yeso para la construcción. Parte 1: Definiciones y especificaciones, 2009.

[25] UNE-EN 13279-2:2014, Yesos de construcción y conglomerantes a base de yeso para la construcción. Parte 2: Métodos de ensayo, 2014.

[26] R. Serrano Somolinos, Estudio del comportamiento frente al fuego del hormigón en masa con adición de nanofibras de carbono (CNFS) y su comparación con hormigones sin adición y con otras adiciones, Tesis Doctoral, Universidad Politécnica de Madrid (España), 2018, https://doi.org/10.20868/UPM. thesis.52181.

[27] C. Piña Ramírez, A. Vidales Barriguete, R. Serrano Somolinos, M. del Río Merino, E. Atanes Sánchez, Analysis of fire resistance of cement mortars with mineral wool from recycling, Construct. Build. Mater. (2020) 120349, https://doi.org/10.1016/ j.conbuildmat.2020.120349.

[28] A. Vidales Barriguete, E. Atanes Sánchez, M. del Río Merino, C. Piña Ramírez, Analysis of the improved water-resistant properties of plaster compounds with the addition of plastic waste, Construct. Build. Mater. 230 (2020) 116956, https://doi org/10.1016/j.conbuildmat.2019.116956.

[29] UNE-EN 1363-1:2015, Ensayos de resistencia al fuego. Parte 1: Requisitos generales, 2015

[30] UNE-EN 1363-2:2000, Ensayos de resistencia al fuego. Parte 2: Procedimientos alternativos y adicionales, 2000.

[31] A. Vidales Barriguete, M. del Río Merino, E. Atanes Sánchez, C. Piña Ramírez, C. Viñas Arrebola, Analysis of the feasibility of the use of CDW as a lowenvironmental-impact aggregate in conglomerates, Construct. Build. Mater. 178 (2018) 83-91, https://doi.org/10.1016/j.conbuildmat.2018.05.011.
[32] L. Alameda, V. Calderón, C. Junco, Á. Rodríguez, J. Gadea, S. Gutiérrez-González, Characterization of gypsum plasterboard with polyurethane foam waste reinforced with polypropylene fibers, Mater. Construcción 66 (2016), https://doi.org/ 10.3989/mc.2016.06015 e100. doi.

[33] F. Ramos, L. Mendes, Recycled high-density polyethylene/gypsum composites: evaluation of the microscopic, thermal, flammability, and mechanical properties, Green Chem. Lett. Rev. 7 (2014) 199-208, https://doi.org/10.1080/ 17518253.2014 .924591$.

[34] M.E. Spontón, Resinas epoxi y benzoxazinas fosforadas y sililadas retardantes a la llama, Tesis Doctoral, Universitat Rovira i Virgili (Tarragona-España), 2008, 97884-691-9480-5/DL:T-22-2009.

[35] M.G. Gómez, Fabricación de componentes constructivos con la fracción plástica de residuos provenientes del reciclado de RAEE, 2019, p. 7, https://doi.org/ 10.33414/ajea.4.371.2019.

[36] S.S. Suresh, S. Mohanty, S.K. Nayak, Composition analysis and characterization of waste polyvinyl chloride (PVC) recovered from data cables, Waste Manag. 60 (2017) 100-111, https://doi.org/10.1016/j.wasman.2016.08.033.

[37] Fundación para la Salud Geoambiental, Dióxido de carbono $\mathrm{CO}_{2}, 2018$. https:// www.saludgeoambiental.org/dioxido-carbono-co2. (Accessed 21 August 2019).

[38] J.I. Vega-Luna, M.A. Lagos-Acosta, G. Salgado-Guzmán, Carbon monoxide concentration monitoring using long-rang technology, Ingenius 18 (2017) 73-82, https://doi.org/10.17163/ings.n18.2017.09.

[39] A. Arnalich Castañeda, J.L. Ayuso Blas, Incendios de interior. Ventilación de incendios, in: Grupo Tragsa (Ed.), Man. Incend., 2015, pp. 84-175. Guadalajara (España). 